\title{
Revisiting gender workspace blind spots
}

\author{
Beth M. Kline-Fath ${ }^{1,2}$ (D) Teresa Victoria $^{3}$
}

Received: 21 May 2020 / Revised: 21 May 2020 / Accepted: 17 June 2020 / Published online: 3 July 2020

(C) Springer-Verlag GmbH Germany, part of Springer Nature 2020

\section{Dear Editors,}

We applaud the articles from Pfeifer et al. [1] and Joshi [2] with regard to gender balance in pediatric radiology. These data are important for the Society for Pediatric Radiology (SPR) as it demonstrates that change definitely needs to occur to support leadership by women in our field. We are in complete agreement with the comments from Sandberg that "it will be quite a day when we look at each other without attention to gender and diversity" [3].

The statistics provided by Pfeifer et al. [1] open the door to understanding the disparity, yet they do not quite describe the problem at hand. Why do women find themselves primarily in the middle of the pyramid rather than at the top [4]? First of all, gender stereotypes are still a part of the global culture [5]. Women, while working, are the ones who generally take on most of the family responsibilities, and there is often little flexibility in their work schedules. In addition, there are definitely negative labels and frank discrimination that act as barriers for women to achieve leadership positions. These come from both genders: it is not just men who need to recognize gender bias; women need to be more assertive and support other women as well. To illustrate this point, Ms. Sandberg [3] discussed how women, when offered a new position, only accept it if they feel they are $100 \%$ qualified, whereas men do so if they meet $60 \%$ of the qualifications, with the thinking that they will acquire the missing $40 \%$ on the job. In addition, aware of discrimination and insecurities, women often

Beth M. Kline-Fath

beth.kline-fath@cchmc.org

1 Department of Radiology and Medical Imaging, Cincinnati Children's Hospital Medical Center, 3333 Burnet Ave., Cincinnati, OH 45229, USA

2 Department of Radiology, University of Cincinnati College of Medicine, Cincinnati, $\mathrm{OH}$, USA

3 Department of Radiology, Children's Hospital of Philadelphia, Philadelphia, PA, USA prefer to remain on the periphery of the room, protecting themselves from unwarranted criticism but crucially limiting their input and growth.

There are problematic societally sanctioned biases about what constitutes leadership that highlight different styles between men and women. Traditionally, the characteristics most admired in a leader have been those typically identified as masculine, including showing assertiveness, demonstrating individualism, and being single-task-oriented. However, many of the traits of a transformational leader, such as collaboration and empowerment, are traditionally thought of as feminine attributes. Women are often more emotionally driven and less aggressive, tend not to act as authoritarian, are more supportive and creative, and are often more quick to give credit to others for their success [6]. In fact, a review of the Fortune 500 companies shows that those with female leadership have much higher productivity in general than those with predominantly male leadership [7]. Look at the current crisis with COVID-19: women are at the top of leadership in handling this pandemic. In New Zealand, for example, as a result of her bold response to the virus, Prime Minister Jacinda Ardern has nearly eradicated the virus from her country [8].

"Blind spots are getting in our way," Sandberg wrote. "It's hard to solve a problem we don't fully see or understand and when it comes to gender in the workplace, too often we miss the scope and scale of the issue [3]."

In our society, inequalities with regard to gender need to be acknowledged and changed. Differences in salary between men and women should be transparent and either amended or explained. These inequalities occur at the highest levels of leadership in medicine, with women department chairs earning 0.88 cents per dollar received by men [9]. A lack of transparency in salary between men and women only conceals persistent inequality. We should engage in a dialogue about this matter openly and not pretend that it is a taboo subject to discuss salary.

Just as pediatric radiology is gender-balanced in the United States, leadership in the SPR and work environments should reflect similar equity. Presidents of medical societies should include women leaders at an even percentage with men. Chair 
positions in our hospitals should be balanced, and women should have the opportunity to pursue and accept any leadership position, even when applying from outside the hiring institution. This is not merely an issue for the applicant: employees deeply care about fairness. In a recent survey, workers noted that fairness and opportunity are the most important factors in determining satisfaction at work [10]. We need to model fairness and opportunity.

One possible impediment in the growth of junior women faculty is that mentorship has been deficient. BOTH women and men in leadership positions should make it a point to act as mentors for young physicians and support them on their journey. Mentors may advise when a junior faculty member is at a crossroad and might inspire at times when the junior mentee fails to see her full potential.

Discrimination and stereotyping of women in society has been brought into the light of day by the "Me Too" movement. We dislike the label because it again emphasizes a gender difference. We need to work as a team to change how women are treated, viewed and appreciated. We challenge each one of us to take these thoughts forward in our practices so that one day, gender and diversity are not descriptors in leadership. The movement for gender equality should be more of a "We Too" inclusive movement of women and men. Together, we can do this.

\section{Compliance with ethical standards}

Conflicts of interest None

\section{References}

1. Pfeifer CM, Gokli A, Reid JR (2020) Advancing from gender equity to women in leadership in pediatric radiology. Pediatr Radiol 50:631-633

2. Joshi A (2020) Gender balance in pediatric radiology: it benefits everyone. Pediatr Radiol 50:634-635

3. Sandberg S (2013) Lean in: women, work, and the will to lead. Alfred A. Knopf, New York

4. Lipsey G, Steiner O, Purvis D, Courant N (1990) Economics. Harper \& Row, New York

5. Hoyt CL, Simon S (2011) Female leaders: injurious or inspiring role models for women? Jepson School of Leadership Studies articles, book chapters and other publications. http://scholarship. richmond.edu/cgi/viewcontent.cgi?article $=1115 \&$ context=jepsonfaculty-publications. Accessed 8 June 2020

6. Radu C, Deaconu A, Frasineanu (2016) Leadership and gender differences - are men and women leading the same way? https:// doi.org/10.5772/65774. Accessed 8 June 2020

7. The White House Project (2009) The White House Project report. Benchmarking women's leadership. http://www.in.gov/icw/files/ benchmark_wom_leadership.pdf. Accessed 8 June 2020

8. Hassan J, O'Grady S (2020, April 20) Female world leaders hailed as voices of reason amid the coronavirus chaos. The Washington Post. https://www.washingtonpost.com/world/2020/04/20/femaleworld-leaders-hailed-voices-reason-amid-coronavirus-chaos/. Accessed 8 June 2020

9. Mensah M, Beeler W, Rotenstein L et al (2020) Sex differences in salaries of department chairs at public medical schools. JAMA Intern Med 180:789-792

10. McKinsey \& Co., Lean In (2019) Women in the workplace 2019: five years in, the path to equality is clear. https:// womenintheworkplace.com/. Accessed 8 June 2020

Publisher's note Springer Nature remains neutral with regard to jurisdictional claims in published maps and institutional affiliations. 